\title{
COMPANY PERFORMANCE MEASUREMENT ANALYSIS WITH BALANCED SCORECARD METHOD AT PT EXPRESS TRANSINDO (PERSERO) JAKARTA FOR PERIOD OF 2012-2016
}

\author{
Husaini Achmad, Wahyuningsih Murni* \\ Faculty of Administrative Science, University of Brawijaya, Malang, Indonesia \\ *E-mail: murni.wahyuningsih95@gmail.com
}

\begin{abstract}
This research aims to determine the performance of companies with balanced scorecard method. This was a descriptive research with a quantitative approach. The samples of this research were 150 customers and 100 employees of PT Express Transindo Utama Tbk. The sampling technique used was a simple random technique. Data were collected from two methods i.e. compiling financial data and distributing questionnaires. Some analysis given to this research is financial ratios analysis and descriptive analysis for the questionnaire. The results of this study show that: (1) financial perspective shows bad result because the accumulation of receivables switches to uncollectible receivables and will harm the company; (2) customer perspective shows good result although the application development for android users are still not maximized; (3) internal business perspective shows good result even though the company has not fully appreciated employees' achievement; and (4) learning and growth perspective shows good result.
\end{abstract}

\section{KEY WORDS}

Performance measurement, balanced scorecard, financial perspective, customer perspective, internal business perspective, learning, growth perspective.

Nowadays, the company performance measurement is essential for management to evaluate the company performance and planning goals in the coming year. "Performance measurement is an assessment carried on various activities in the value chain of the company" (Yuwono, 2007). Various information is collected so that the work can be reduced and accountable. This is done to promote efficiency and effectivity of all business processes. The description of company performance can be obtained from two sources, namely financial information and non-financial information. Financial information is obtained from budgeting to control costs. Non-financial information is a key factor the set a strategy which is intended to carry out the set goals. A large part of the organizations measures their performance by emphasizing on their finances (financial perspective).

Looking at company performance just from the financial aspect that orientates towards the past. In addition, there are so many companies that work out earnings management strategies so that the financial reports presentation is beautified and able to influence the financial report users in the decision-making process (Niven, 2003).

Actually, the non-financial perspectives associated with company performance management provide a powerful influence on corporate profits, for example, customer relationship, an innovation made by a company and employees' loyalty to the business process.

An effective performance measurement is able to achieve the overall perspective in a company in which the performance measurement is summarized in a strategic measurement system called Balanced Scorecard developed by Norton in 1990. "Balanced scorecard is a contemporary management tool designed to increase company capacity in multiplying financial performance on a continuous basis (sustainable outstanding financial performance)" (Mulyadi, 2009). Balance scorecard measurements to assess performance is divided into 4 (four) perspectives i.e. financial perspective, customer perspective, per-internal business perspective, and learning and growth perspective. Tunggal (2002) explains four perspectives in balanced scorecard as follows: 
Financial Perspective. Measuring profitability and market value among other companies, as an indicator of how good a company to satisfy the owner and the shareholder. Customer Perspective. Measuring the quality, service, and the low cost compared to other companies, as an indicator of how good a company to satisfy the customer.

Perspective of Internal Business Process. Measuring the company's effectivity and efficiency in producing goods and services.

Learning and Growth Perspective. Measuring company performance to develop and utilize human resources so that the strategic goals can be achieved for now and in the future.

One of the companies proper to observe its company performance by using a balanced scorecard approach is PT. Express Transindo Utama Tbk. PT. Express Transindo Utama Tbk is a land transportation company that is engaged in transporting passengers. An interest in choosing PT. Express Transindo Utama Tbk as the object of this research is that PT Express Transindo Utama Tbk is the first taxi company in Indonesia. In addition, analysis data of the financial statement of PT Express Transindo Utama Tbk in ROA (Return on Property) section shows a significant decrease from 2014 until 2016 in which 2016 was the lowest ROA point during the 2012-2016 period as indicates in this following table.

Table 1 - ROA of PT Express Transindo Utama Tbk Year 2012-2016

\begin{tabular}{|c|c|c|c|c|c|}
\hline \multirow{2}{*}{ Company Name } & \multicolumn{5}{|c|}{ Year } \\
\cline { 2 - 6 } & 2012 & 2013 & 2014 & 2015 & 2016 \\
\hline PT Express Transindo Utama Tbk & $4.45 \%$ & $6.21 \%$ & $3.93 \%$ & $1.12 \%$ & $-3.02 \%$ \\
\hline
\end{tabular}

Source: www.idx.id (retrieved on 1 August 2017 at 14.14)

The reason to choose ROA as the reference of either good or bad condition of company financial due to ROA illustrates the company's ability to generate profits of every asset owned. In addition, the appointment of PT Exspress Transindo Utama to be the research object also depends on the comparison of ROA among the similar transportation companies (especially taxi) and listen on ISE. The company that became the comparator of this research is PT Blue Bird who just joined ISE in 2014. The table below illustrates ROA comparison between PT Express Transindo Utama Tbk and PT Blue Bird Tbk.

Table 2 - The Comparation of ROA PT Express Transindo Utama with PT Blue Bird

\begin{tabular}{|l|c|c|c|c|l|}
\hline \multirow{2}{*}{ Company Name } & \multicolumn{4}{|c|}{ Year } \\
\cline { 2 - 6 } & 2012 & 2013 & 2014 & 2015 & 2016 \\
\hline PT Express Transindo Utama Tbk & $4.45 \%$ & $6.21 \%$ & $3.93 \%$ & $1.12 \%$ & $-3.02 \%$ \\
\hline PT Blue Bird Tbk & - & - & $10.32 \%$ & $11.59 \%$ & $4.98 \%$ \\
\hline
\end{tabular}

Source: www.idx.id (retrieved on 1 August 2017 at 14.14)

As the data presented in the table above, PT Express Transindo Utama and PT Blue Bird experienced a decline in ROA for almost the entire year, it means the asset owned by those two companies are not used efficiently in generating profits for the company. Based on the graph above, PT Blue Bird still has a way better percentage of ROA than PT Express Transindo Utama, especially in 2016. The ratio data above illustrates that PT Express Transindo Utama has much more shortcomings than PT Blue Bird. For that matter, this research chooses PT Express Transindo Utama as the research object. However, the decline in ROA never shown the real condition of a company because it only measures from one perspective only i.e. financial perspective. On the other hand, based on the research theme, that isassessing performance with the balanced scorecard method, so this study not only can be assessed from the financial perspective but also other perspectives found in the balanced scorecard method, thai is customer perspective which will give an illustration of the intended segment. Internal business process perspective which will give a description of a process that must be build to serve customer and also learning and growth perspective as the driver to build the competence of personal, information system infrastructure and the situation of working environment required to realize financial target, customer, and the process of internal business (Mulyadi and Johny, 2001). According to the explanation above, this study will be 
about company performance that is not only assessed from the financial status but also from another perspective like customers, internal business, and learning and growth.

\section{LITERATURE REVIEW}

Performance assessment is a periodical determination of the organization's operational, part of an organization, and its personnel, based on the target, and criteria that have been set before. "The main goal of the performance assessment is to motivate the personnel to reach their organizational target and to adhere the standard of behavior which has been set previously to produce an action and generate a result as expected by the organization" (Mulyadi, 2001). "The result of the research will be later used as the feedback which will give information about the implementation achievement of a planning as well as the adjustment that an organizations needs to implement for the sake of planning and controlling" (Yuwono, et al, 2007).

Performance assessment also can be defined as a process to set a joint understanding of what will achieve, and an approach to manage and develop a person by an improvement which will be achieved in a short or long time. This increase is not only because of the system that is driven by a management to regulate their employees' performance, but also through an approach to manage and develop people who enable them to organize their own development and performance in a clear target framework and standardized approach with their supervisors (Rivai, 2005).

Yuwono et al. (2002) defined balanced scorecard as "a management system, a measurement, and control that is quickly, properly, and comprehensively able to give an understanding of a business performance." "Balance scorecard also can be defined as a management concept that helps to translate a strategy into an action (Gaspersz, 2005). Meanwhile, based on Luis and Biromo (2007) balanced scorecard is "one of the performance management tools that can help the organization to translate a vision and strategy into an action by utilizing a group of financial and non-financial indicator that all of them have causality."

A company's financial performance measurement relates to the financial ratio measurement that will describe the company's financial condition or situation during a particular period. The financial ratio of this research is:

Current Ratio:

Current Ratio $=\frac{\text { Current Assets }}{\text { Current Liabilities }} \times 100 \%$

(Rudianto, 2014:193)

Quick Ratio:

$\begin{aligned} & \text { Quick } \\ & \text { Ratio }\end{aligned}=\frac{\text { Cash + Claim + Securities }}{\text { Current Liabilities }} \times 100 \%$

(Rudianto, 2014:193)

Cash Ratio:

Cash Ratio $=\quad \frac{\text { Cash }+ \text { Securities }}{\text { Current Liabilities }} \quad \times 100 \%$

(Rudianto, 2014:193) 
Eurasia: Economics \& Business, 6(12), June 2018

DOI https://doi.org/10.18551/econeurasia.2018-06

Account Receiveable Turnover:

\begin{tabular}{|l|l|}
\hline A/R Turnover $=$ & $\begin{array}{c}\text { Sales (credit) } \\
\text { Receivables Average }\end{array}$ \\
\hline
\end{tabular}

(Rudianto, 2014:194)

TATO:

TATO $=\quad \begin{aligned} & \text { Sales } \\ & \text { Total Asset }\end{aligned}$

(Rudianto, 2014:194)

Debt to Total Asset:

\begin{tabular}{|c|c|c|c|}
\hline $\begin{array}{c}\text { Debt To Total } \\
\text { Asset }\end{array}$ & $=$ & $\frac{\text { Total Debt }}{\text { Total Asset }}$ & x $100 \%$ \\
\hline
\end{tabular}

(Rudianto, 2014:194)

Total Debt to Equity:

\begin{tabular}{|c} 
Total Debt To \\
Equity
\end{tabular}$=\frac{\text { Total Debt }}{\text { Total Equity }} \times 100 \%$

(Rudianto, 2014:193)

Gross Profit Margin:

\begin{tabular}{|lc|}
\hline $\begin{array}{c}\text { Gross Profit } \\
\text { Margin }\end{array}$ & $=\begin{array}{c}\text { Gross Profit } \\
(\text { EBIT }) \\
\text { Sales }\end{array}$ \\
\hline
\end{tabular}

(Kasmir, 2008:200)

Net Profit Margin:

\begin{tabular}{|c|c|c|c|}
\hline \multirow[t]{2}{*}{ Net Profit Margin } & $=$ & $\begin{array}{c}\text { Net Income } \\
(\mathrm{EAIT})\end{array}$ & $x 100 \%$ \\
\hline & & Sales & \\
\hline
\end{tabular}

(Kasmir, 2008:200)

ROI (Return on Investment):

\begin{tabular}{|ll|} 
ROA $=$ & $\frac{\text { Net Income }}{\text { Total Asset }}$ \\
\hline
\end{tabular}

(Rudianto, 2014:192)

ROE (Return on Equity):

ROE $=\frac{\text { Net Income }}{\text { Total Equity }} \times 100 \%$

(Rudianto, 2014:192) 
Customer Perspective. Kaplan dan Norton (1996) expect a company to make a market segmentation and determine its most possible market target to serve as a target in accordance with the ability, resources, and company's long-term planning. "Customer perspective describes the way the company differentiates itself from the competitor to attract, maintain and deepen relationships with target customer" (Anthony, et al., 2012). According to Lodovikusa Dissid (JWMA, 2002), balanced scorecard contains two groups of measurements in the customer perspective, namely:

- Measurement Group of Consumer Core;

- Measurement Group of Consumer Value.

Internal Business Process Perspective. On the internal business process perspective, a manager identifies various programs that are very important to achieve customer' and shareholder's goals. Every business has a particular series of process to create value for the customer and give a good financial result. Mulyadi and Johny (2001) formulate three strategic targets to build an internal business process. Those three strategic targets are:

- Innovation Process;

- Operational Process;

- After Sales Service Process.

Learning and Growth Perspective. The fourth perspective in the balanced scorecard aims to develop goals and measurement that encourage the company's learning and growth. A goal that was set up in the customers' perspective and the process of internal business identify what a company must master to result in a special performance. The objective of learning and growth perspective is to provide an infrastructure that enables the goals in other three perspectives can be achieved. The main measurement groups to assess learning and growth perspectived according to Kaplan and Norton (2000) include:

- Customer Satisfaction;

- Customer Retention;

- Employee Productivity.

\section{METHODS OF RESEARCH}

This was a descriptive research with a quantitative approach. This study was carried out in PT. Express Transindo Utama, located at Jl. This research focuses to cover four perspectives in balanced scorecard, namely:

- Financial Perspective;

- Customer Perspective;

- Internal Business Perspective;

- Learning and Growth Perspective.

\section{RESULTS AND DISCUSSION}

The calculation result shows that in 2012-2015, PT Express Transindo Utama Tbk did not experience liquidity since the currents assets cover the total debt owned by a company even though the ratio does not reach 2:1. In 2016, PT. Express Transindo Utama Tbk experienced over liquid because at the same year, PT Express Transindo Utama Tbk paid off bank loans which drastically reduced total short-term debt.

Table 3 - Liquidity Ratio

\begin{tabular}{|c|c|c|c|c|c|}
\hline \multirow{2}{*}{ Liquidity Ratio } & \multicolumn{5}{|c|}{ Year } \\
\cline { 2 - 6 } & 2012 & 2013 & 2014 & 2015 & 2016 \\
\hline Current Ratio & $145.53 \%$ & $103.78 \%$ & $131.07 \%$ & $145.22 \%$ & $407.69 \%$ \\
\hline Quick Ratio & $126.98 \%$ & $79.90 \%$ & $96.88 \%$ & $130.73 \%$ & $327.84 \%$ \\
\hline Cash Ratio & $107.06 \%$ & $54.87 \%$ & $42.05 \%$ & $32.06 \%$ & $9.30 \%$ \\
\hline
\end{tabular}

Source: Financial Data and Ratios PT Express Transindo Utama. 
Table 4 - Activity Ratio

\begin{tabular}{|c|c|c|c|c|c|}
\hline \multirow{2}{*}{ Activity Ratio } & \multicolumn{5}{|c|}{ Year } \\
\cline { 2 - 6 } & $\mathbf{2 0 1 2}$ & $\mathbf{2 0 1 3}$ & $\mathbf{2 0 1 4}$ & $\mathbf{2 0 1 5}$ & $\mathbf{2 0 1 6}$ \\
\hline $\begin{array}{c}A / R \\
\text { Turnover }\end{array}$ & 7,0063 & 4,7740 & 3,1631 & 2,3090 & 1,1106 \\
\hline TATO & 0,2921 & 0,3214 & 0,2955 & 0,3364 & 0,2417 \\
\hline
\end{tabular}

Source: Financial Data and Ratio of PT Express Transindo Utama.

The results show that the total asset getting low causes a decrease in income due to the manageable assets to generate profits for the company are also the same. Later on, receivable turnover of PT Express Transindo Utama Tbk is far below the average standard, which means the debt turnover is very slow which causes debt accumulation. The largest accumulation of debts originates from the driver who operates Express taxi, it happened because the mandatory deposit that does not meet the daily target. The driver is obligated to deposit 240,000/day/ driver, however; the majority of the drivers cannot fulfill the target because of the string competition between conventional and online-based transportation in getting customers. Even though the company has lowered its deposit target to $150,000 /$ day/driver, the matter has actually no effect on the decrease of the company's total debt.

The calculation result shows that during 2012-2016, the funding of PT Express Transindo Utama much more sources from the assets that the debts although the amount of assets decreased due to the down payment used to redeem the car that would be operated by the drivers were still small because the more little a person who wants to be conventional taxi driver along with the rise of online-based taxi. The company's total debt from 2015 until 2016 was also decreasing due to the company start paying off its debt to the bank.

Table 5 - Solvability Ratio

\begin{tabular}{|c|c|c|c|c|c|}
\hline \multirow{2}{*}{ Solvability Ratio } & \multicolumn{5}{|c|}{ Year } \\
\cline { 2 - 5 } & 2012 & 2013 & 2014 & 2015 & 2016 \\
\hline Debt to Total Asset & $61 \%$ & $63 \%$ & $70 \%$ & $68 \%$ & $71 \%$ \\
\hline Debt to Total Equity & $160 \%$ & $168 \%$ & $237 \%$ & $213 \%$ & $247 \%$ \\
\hline
\end{tabular}

Source: Financial Data and Ratios of PT Express Transindo Utama.

Table 6 - Profitability Ratio

\begin{tabular}{|c|c|c|c|c|c|}
\hline \multirow{2}{*}{ Profitability ratio } & \multicolumn{5}{|c|}{ Year } \\
\cline { 2 - 6 } & 2012 & 2013 & 2014 & 2015 & 2016 \\
\hline Gross Profit Margin & $35 \%$ & $32 \%$ & $45 \%$ & $35 \%$ & $12 \%$ \\
\hline Net Profit Margin & $15 \%$ & $19 \%$ & $13 \%$ & $3 \%$ & $-30 \%$ \\
\hline ROI & $4 \%$ & $6 \%$ & $4 \%$ & $1 \%$ & $-7 \%$ \\
\hline ROE & $12 \%$ & $17 \%$ & $13 \%$ & $4 \%$ & $-25 \%$ \\
\hline
\end{tabular}

Source: Financial Data and Ratios of PT Express Transindo Utama.

The calculation results indicate that the decline in income does not balance with a decrease in the direct burden resulting in the margin profit of PT Express Transindo Utama is below the average standard. That matter was aggravated by the decline of assets and equity which do not balance with the income decline that make the financial performance of PT Express Transindo Utama look bad.

Customer Perspective. Table 7 shows the "agree" result for PT Express Transindo Utama Tbk for its effort to provide a good service, build a good relationship with customer and the nice image and reputation of PT Express Transindo Utama, which means almost all consumers of PT Express Transindo Utama are satisfied with the service of PT Express Transindo Utama. 
Eurasia: Economics \& Business, 6(12), June 2018

DOI https://doi.org/10.18551/econeurasia.2018-06

Table 7 - Customer perspective Level of Service Provided by PT Expres Transindo Utama

\begin{tabular}{|c|c|c|c|c|c|c|c|c|c|c|c|}
\hline \multirow{4}{*}{ Item } & \multicolumn{10}{|c|}{ Score } & \multirow{4}{*}{ Mean } \\
\hline & \multirow{2}{*}{\multicolumn{2}{|c|}{$\begin{array}{c}1 \\
\text { STS }\end{array}$}} & \multirow{2}{*}{\multicolumn{2}{|c|}{$\begin{array}{c}2 \\
T S\end{array}$}} & \multirow{2}{*}{\multicolumn{2}{|c|}{$\frac{3}{\mathrm{RR}}$}} & \multirow{2}{*}{\multicolumn{2}{|c|}{$\frac{4}{S}$}} & \multirow{2}{*}{\multicolumn{2}{|c|}{$\frac{5}{S S}$}} & \\
\hline & & & & & & & & & & & \\
\hline & $f$ & $\%$ & $\mathrm{~F}$ & $\%$ & $f$ & $\%$ & $f$ & $\%$ & $f$ & $\%$ & \\
\hline 1 & 2 & $2 \%$ & 5 & $6 \%$ & 28 & $32 \%$ & 24 & $27 \%$ & 29 & $33 \%$ & 3.83 \\
\hline 2 & 3 & $3 \%$ & 9 & $10 \%$ & 30 & $34 \%$ & 28 & $32 \%$ & 18 & $20 \%$ & 3.56 \\
\hline 3 & 1 & $1 \%$ & 6 & $7 \%$ & 31 & $35 \%$ & 26 & $30 \%$ & 24 & $27 \%$ & 3.75 \\
\hline 4 & 2 & $2 \%$ & 10 & $11 \%$ & 23 & $26 \%$ & 33 & $38 \%$ & 20 & $23 \%$ & 3.67 \\
\hline 5 & 4 & $5 \%$ & 2 & $2 \%$ & 22 & $25 \%$ & 30 & $34 \%$ & 30 & $34 \%$ & 3.91 \\
\hline
\end{tabular}

Source: Data Processed, 2018.

Table 8 - Perspective Level of Internal Business on PT Express transindo Utama

\begin{tabular}{|c|c|c|c|c|c|c|c|c|c|c|c|}
\hline \multirow{4}{*}{ Item } & \multicolumn{10}{|c|}{ Score } & \multirow{4}{*}{ Mean } \\
\hline & & 1 & & & & & & 4 & & 5 & \\
\hline & \multicolumn{2}{|c|}{ Never } & \multicolumn{2}{|c|}{ Almost Never } & \multicolumn{2}{|c|}{ Sometimes } & \multicolumn{2}{|c|}{ Often } & \multicolumn{2}{|c|}{ Always } & \\
\hline & $f$ & $\%$ & $\mathrm{~F}$ & $\%$ & $f$ & $\%$ & $f$ & $\%$ & $f$ & $\%$ & \\
\hline 1 & 2 & $2 \%$ & 8 & $9 \%$ & 25 & $28 \%$ & 42 & $48 \%$ & 9 & $10 \%$ & 3.56 \\
\hline 2 & 1 & $1 \%$ & 2 & $2 \%$ & 20 & $23 \%$ & 54 & $61 \%$ & 9 & $10 \%$ & 3.79 \\
\hline 3 & 0 & $0 \%$ & 1 & $1 \%$ & 32 & $36 \%$ & 43 & $49 \%$ & 10 & $11 \%$ & 3.72 \\
\hline 4 & 0 & $0 \%$ & 3 & $3 \%$ & 16 & $18 \%$ & 52 & $59 \%$ & 15 & $17 \%$ & 3.92 \\
\hline 5 & 0 & $0 \%$ & 0 & $0 \%$ & 8 & $9 \%$ & 63 & $72 \%$ & 15 & $17 \%$ & 4.08 \\
\hline
\end{tabular}

Source: Data processed, 2018.

Table 8 shows the result of "often" from employees in PT Express Transindo Utama Tbk. It means the company has run well in terms of innovation, operational process, and after-sales service.

Table 9 - Perspective Level of Learning and Growth Regarding PT Express Transindo Utama Tbk

\begin{tabular}{|c|c|c|c|c|c|c|c|c|c|c|c|}
\hline \multirow{4}{*}{ Item } & \multicolumn{10}{|c|}{ Score } & \multirow{4}{*}{ Mean } \\
\hline & \multirow{2}{*}{\multicolumn{2}{|c|}{$\frac{1}{\text { Never }}$}} & \multirow{2}{*}{\multicolumn{2}{|c|}{$\frac{2}{\text { Almost Never }}$}} & \multirow{2}{*}{\multicolumn{2}{|c|}{$\frac{3}{\text { Sometimes }}$}} & \multirow{2}{*}{\multicolumn{2}{|c|}{$\frac{4}{\text { Often }}$}} & \multirow{2}{*}{\multicolumn{2}{|c|}{$\frac{5}{\text { Always }}$}} & \\
\hline & & & & & & & & & & & \\
\hline & $f$ & $\%$ & $f$ & $\%$ & $f$ & $\%$ & $f$ & $\%$ & $f$ & $\%$ & \\
\hline 1 & 5 & $6 \%$ & 11 & $13 \%$ & 26 & $30 \%$ & 40 & $45 \%$ & 4 & $5 \%$ & 3.31 \\
\hline 2 & 12 & $14 \%$ & 17 & $19 \%$ & 30 & $34 \%$ & 23 & $26 \%$ & 4 & $5 \%$ & 2.88 \\
\hline 3 & 0 & $0 \%$ & 0 & $0 \%$ & 8 & $9 \%$ & 73 & $83 \%$ & 5 & $6 \%$ & 3.97 \\
\hline 4 & 6 & $7 \%$ & 5 & $6 \%$ & 21 & $24 \%$ & 43 & $49 \%$ & 11 & $13 \%$ & 3.56 \\
\hline 5 & 9 & $10 \%$ & 9 & $10 \%$ & 23 & $26 \%$ & 34 & $39 \%$ & 11 & $13 \%$ & 3.34 \\
\hline
\end{tabular}

Source : Data processed, 2018.

Table 9 shows the result of "often" from the employees for PT Express Transindo Utama Tbk which means the company is good to manage Human Resources and to utilize employees productivity. On the other hands, the calculation of the total employees shows the low retention of an employee due to the increase of the employees who leave the company, in other words, employee's loyalty in a company is low. On the other hands, the calculation of the total employees shows the low retention of an employee due to the increase of the employees who leave the company, in other words, employee's loyalty in a company is low.

\section{CONCLUSION}

Financial perspective owned by PT Express Transindo Utama Tbk shows a not good result. The biggest problem is in the company's debt due to the driver gets difficult to get a customer who wants to use a conventional taxi. That matter causes the driver's daily deposit is always less than the company's target, even when the company decreases the target of daily deposit, the driver still get difficult in fulfilling the obligation. The lack of driver's daily deposit has an impact on the swelling of company's debt which has a large possibility to change into uncollectible receivables due to the large number who stop being a conventional 
taxi driver.

Customer perspective, of course, gets good value but there are several points that get a bad value in which if there are no changes will give a significant impact for the company. For example is an improvisation of the service offered which will make the customer happy to use the service of PT Express Transindo Utama. Based on the existing conditions, PT Express is always too late in releasing innovation compared to its competitor (PT Blue Brdrd). PT Blue Bank has already been working together with online transportation company (GRAB), then followed by the Expres working together with UBER. In fact, nowadays, UBER has been acquired by GRAB which means Expres is already not working together with UBER. In addition, the application developed by Express (My Trip) for android does not more interesting and is lack of user-friendly compared to the application provided by its competitor, which is Blue Bird. Hence, even though there is a promo for the user of My Trip application, the majority of passenger does not know this matter due to she/he does not know the application which is less attractive and user-friendly.

Internal business perspective getting a good value from the employee of PT Express transindo Utama does not mean that all go well and properly. For example is the employee who gets small appreciation when giving a positive thought for the company improvement so that resulting in the employee has less motivation to do the best for the company.

Learning and Growth Perspective gets a good value from the employees of PT Express Transindo Utama but there are still several things being the concern. For example, PT Express Transindo Utama must update technology applied in the operational activity.

\section{SUGGESTIONS}

Based on the result of an analysis, the discussion and conclusion that has been done before, it is expected that PT Express Transindo Utama Tbk will be able to increase motivation and maximize human resources as the existing asset to refine the accumulation of debt happened. The way the drive can do is to leave home earlier to get a customer, the driver is lead to target customer who leaver for very early to reach his/her working place with the expectation they want to use a taxi as a transportation to go to their respective destination. Another way that can be done by the driver is going around which means not staying in one place only. Berkeliling Going around is a very effective way of getting passengers because there are still so many passengers who need it as transportation tool they choose. Also, the company should more respect the employees who give new ideas for company improvement so that will be many more employees motivated to continuously give their best ideas for the company.

Also, the company should more respect the employees who give new ideas for company improvement so that will be many more employees motivated to continuously give their best ideas for the company. In addition, the passenger should also provide with the best service by improving the system. It is unfortunate if a big company like Express has allocated much money but the application is not liked by its consumer so that the order or promo given by company is not delivered to the consumer.

PT Express Transindo Utama Tbk also should apply balance scorecard analysis in measuring company's performance to generate a comprehensive measurement from the four perspectives i.e. financial perspective, customer perspective, internal business process perspective, and learning and growth perspective. Therefore, the orientation of company performance is not only for today but also for the future by considering the strong competition and the needs of safe and convenient transportation for the community who is getting increase along with the increase of total community, especially in a big city where PT Express Transindo Utama operates.

\section{REFERENCES}

1. Anthony., \& Govindrajan. (2005). Management Control System (1st Ed). Jakarta: Salemba Empat. 
2. Gaspersz, V. (2007). TOPS (Team-Oriented Problem Solving) Panduan Kreatif Solusi Masalah Untuk Sukses. Jakarta: PT Gramedia Pustaka Utama.

3. (2005). Total Quality Management. Jakarta: PT Gramedia Pustaka Utama.

4. Kaplan, R. S., \& Norton, D. P. (2000). Balanced Scorecard: Menerapkan Strategi Menjadi Aksi. Jakarta: Erlangga.

5. Luis, S., \& Prima, A. B. (2007). Step by Step in Cascading Balanced Scorecard to Functional Balanced Scorecard. Jakarta: PT Gramedia Pustaka Utama.

6. Mulyadi. (2009). Akuntansi Biaya (5th Ed). Yogyakarta: Akademi Manajemen Perusahaan.

7. (2009). Sistem Terpadu Pengelolaan Kinerja Personel Berbasis Balanced Scorecard. Yogyakarta: UPP STIMYKPN.

8. (2007). Sistem Perencanaan dan Pengendalian Manajemen ( $3^{\text {rd }}$ Ed). Jakarta: Salemba Empat.

9. (2007). Sistem Terpadu Kinerja Personel Berbasis Balanced Scorecard. Yogyakarta: Sekolah Tinggi llmu Manajemen YKPN.

10. (2001). Sistem Akuntansi. Jakarta: Salemba Empat.

11. Mulyadi., \& Johny. (2001). Balanced Scorecard: Alat Manajemen Kontemporer untuk Pelipatgandaan Kinerja Perusahaan. Jakarta: Salemba Empat.

12. (2001). Sistem Perencanaan dan Pengendalian Manajemen: Sistem Pelipatganda Kinerja Perusahaan. Jakarta: Salemba Empat.

13. Niven, P. R. (2003). Balanced Scorecard: Step - By - Step for Government and Nonprofit Agencies. New York: John Wiley \& Sons, Inc.

14. Rivai, V. (2005). Performance Apprasial. Jakarta: PT Raja Grafindo Persada.

15. Tunggal, W. A. (2001). Pengukuran Kinerja dengan Balanced Scorecard. Jakarta: Harvarindo.

16. Tunggal, W. A. (2002). Pengukuran Kinerja dengan Balanced Scorecard. Jakarta: Harvarindo.

17. Widjaja, T. A. (2003). Pengukuran Kinerja dengan Balanced Scorecard. Yogyakarta: Harvarindo.

18. Yuwono, S., et al. (2006). Balanced Scorecard: Petunjuk Praktis Penyusunan Menuju Organisasi yang Berfokus pada Strategi. Jakarta: PT Gramedia Pustaka Utama.

19. (2002). Petunjuk Penyusunan Balanced Scorecard Menuju Organisasi yang Berfokus pada Strategi (4th Ed). Jakarta: PT Gramedia Pustaka Utama. 